\title{
Beyond the Black Box of Demography: Board Processes and Task Effectiveness within Italian Firms
}

\begin{abstract}
In this paper we analyze boards of directors as workgroups, i.e., groups of people that perform one or more tasks within an organizational context. Building on previous studies, we developed a model that relates group's social-psychological processes to three different board tasks: service, monitoring, and networking. We tested our model through a survey on 301 large manufacturing firms in Italy. Our findings support the idea that (a) process variables and, to a limited extent, demographic variables significantly influence board task performance; (b) board processes have a different impact on each specific board task; (c) board task performance varies depending upon firm and industry characteristics.
\end{abstract}

Keywords: Board processes, Board Task Performance, Italy 


\section{Beyond the Black Box of Demography: Board Processes and Task Effectiveness within Italian Firms}

Despite the increasing attention on boards of directors, there is still scant evidence on what determines their effectiveness (Daily, Dalton and Cannella, 2003; Roberts, McNulty and Stiles, 2005). Previous studies failed to provide clear evidence of the hypothesized relationship between board's demographic characteristics on the one hand and the firm performance on the other (Dalton et al., 1998; Dalton et al., 2003; Hermalin and Weisbach, 2003). The theoretical and methodological approaches traditionally adopted may explain this lack of empirical evidence. It has been suggested that reliance on agency theory and the extensive use of demographic variables may limit our understanding of boards of directors (Daily, Dalton and Cannella, 2003).

Agency theory dominates studies of corporate governance (Dalton et al. 1998; Daily, Dalton and Cannella, 2003). Indeed, the agency framework provided the first satisfactory explanation of the separation between ownership and control in large American corporations (Jensen and Meckling, 1976). It describes the board of directors as an instrument designed to deal with the conflict of interests between management and shareholders (Shleifer and Vishny, 1997) and places great emphasis on the board's monitoring role. Furthermore, from a methodological viewpoint, agency theory has the advantage of being simple and of being founded on a wellaccepted model of human behavior (Daily, Dalton and Cannella, 2003); these features have contributed to its widespread diffusion. The extensive reliance on agency theory may have led scholars to place too much emphasis on the board monitoring task, diverting their attention away from other perspectives (Daily, Dalton and Cannella, 2003; Stiles and Taylor, 2001) such as resource dependence (Pfeffer and Salancik, 1978) or stewardship theory (Davis, Schoorman and Donaldson, 1997). Only few scholars have tried to compare agency theory with competing approaches - such as institutional theory (Judge and Zeithaml, 1992) - or to combine agency theory with other complementary perspectives - such as resource dependence (Hillman and Dalziel, 2003).

As to demographic variables, most research on boards of directors has focused on establishing a relationship between these variables (e.g., board size, CEO duality, outsider ratio and CEO ownership) and the board or the firm performance (Daily, Dalton and Cannella, 2003; Johnson, Daily and Ellstrand, 1996). However, the ability of demographic variables to capture the characteristics of intermediate processes leading to board effectiveness has been debated 
for long time. Pfeffer (1983) argued that demographic variables may be superior compared to perceptual measures (such as attitudes or values), since the former are directly observable and hence more reliable compared to the latter. Furthermore, assuming that there is congruence between demographic predictors and subjective concepts (Lawrence, 1997), reliance on demographic variables offers the methodological advantage of parsimony: it allows scholars to limit their focus on a few, easy-to-measure variables (input: demographic variables; output: behavioral or outcome variables) whilst ignoring intervening processes which are more difficult to observe.

However, it has been argued that this approach prevents the researcher from gaining any understanding of the processes through which inputs affect outputs (Pettigrew, 1992; Pye and Pettigrew, 2005; Roberts, McNulty and Stiles, 2005). For this reason, in the presence of complex processes and group dynamics, as in board decision-making, the use of demographic variables can lead to biased results (Dalton et al., 1998; Dalton et al., 2003; Johnson, Daily and Ellstrand, 1996; Forbes and Milliken, 1999).

In order to overcome these limitations, scholars have recently emphasized the need to gain access to process data and to consider theoretical perspectives other than agency theory (Hermalin and Weisbach, 2003; Huse, 2000; Pye and Pettigrew, 2005; Stiles and Taylor, 2001). A more eclectic approach has been recommended (Daily, Dalton and Cannella, 2003). This paper contributes to the literature on boards of directors by providing a more detailed analysis of the relationship between board processes and board task performance. Drawing from the literature on group dynamics, we consider boards as workgroups, i.e., groups of people "that perform one or more tasks within an organizational context" (Bettenhausen, 1991: 346). Building on previous works (Forbes and Milliken, 1999; Huse, 2005; Zahra and Pearce, 1989), we developed a model that relates board processes to board task performance. By board processes we mean social-psychological processes pertaining to critical discussion, group participation and interaction, and the exchange of information (Forbes and Milliken, 1999). Board task performance refers to the board's ability to execute its service, monitoring, and networking tasks (Johnson, Daily and Ellstrand, 1996; Stiles and Taylor, 2001; Zahra and Pearce, 1989). We tested our model through a survey of Italy's largest manufacturing companies. Our findings support the idea that (i) board processes have a positive and significant relationship with board task performance; (ii) board processes have a different impact on each specific board task; (iii) the level of board task performance depends upon the external context of the firm.

In the next section, we ground our model in the existing theoretical frameworks. In the 
following section, we describe the research method, and present sample, data collection and variables. We then present the results of our study and, in the final section, discuss our main findings, highlighting their limitations and implications for future research.

\section{Theory and Hypotheses}

\section{Board tasks}

Scholars in the field of corporate governance maintain that boards of directors perform three key tasks: (i) the service task, i.e., the revision and evaluation of strategic decisions and the provision of technical advice so as to improve the firm's strategic plans; (ii) the monitoring task, i.e., the control of managers and the monitoring of the firm performance so as to safeguard shareholders' interests; (iii) the networking task, i.e., the provision of facilitated access to external resources and the reinforcement of the firm's legitimation (Goodstein, Gautam and Boeker, 1994; Johnson, Daily and Ellstrand, 1996; Stiles and Taylor, 2001; Zahra and Pearce, 1989).

The board service task. Boards of directors participate in the strategic decision-making process and support the top management in defining the strategic context of the firm (Stiles and Taylor, 2001). The board service task includes a set of related activities, such as evaluating and selecting strategic alternatives that have been developed by top managers, providing advice to improve the quality of strategic decisions, and so on (Andrews, 1980; Demb and Neubauer, 1992; Lorsch and MacIver, 1989; Styles and Taylor, 2001). A high level of service task performance is believed to have a positive impact on a firm's long-term competitive advantage (Andrews, 1980).

The board monitoring task. Monitoring managerial behavior is considered to be the principal task of the board (Berle and Means, 1932). According to agency theory, the board of directors is an instrument designed to safeguard shareholders' interests from possible opportunistic behavior of executives (Fama and Jensen, 1983; Shleifer and Vishny, 1997). In the agency framework, boards of directors and top managers have different roles: managers have the duty to perform "decision management" (i.e., to generate strategic alternatives for resource utilization and execute these decisions), whereas boards of directors perform "decision control" (i.e., to select the course of conduct and control the firm performance) (Fama and Jensen, 1983). The board of directors performs its monitoring role through managerial control systems and the assessment of top management behavior (Stiles and Taylor, 2001). The monitoring task includes a set of related activities, such as the control of firm performance, 
the monitoring of firm's activities, the assessment of CEO behaviors, and so on (Johnson, Daily and Ellstrand, 1996; Stiles and Taylor, 2001; Zahra and Pearce, 1989).

The board networking task. The board of directors can also facilitate access to resources critical to the firm success or survival (Pfeffer, 1972). Boards play an important role spanning boundaries, making timely information available to managers (Pfeffer and Salancik, 1978). Outside directors with high prestige and high status are usually co-opted by managers to increase the legitimation of the firm within its environment (Johnson, Daily and Ellstrand, 1996; Zahra and Pearce, 1989). Furthermore, representatives of external stakeholders can be co-opted in order to facilitate the firm's access to critical resources (i.e., the co-optation of executives from financial institutions to facilitate access to financial resources) (Johnson, Daily and Ellstrand, 1996).

\section{Board Processes}

Boards of directors are episodic decision-making groups facing complex tasks whose output is largely cognitive in nature (Forbes and Milliken, 1999). As a consequence, boards are vulnerable to interaction difficulties, and their effectiveness largely depends upon socialpsychological processes, such as group participation, critical discussion, and exchange of information (Forbes and Milliken, 1999; Milliken and Vollrath, 1991; Samra-Fredericks, 2000a and 2000b). Three specific board processes have been proposed as antecedents of board task performance: cognitive conflict, efforts norms, and use of knowledge and skills (Forbes and Milliken, 1999; Huse, 2005). The theoretical model linking board processes to board task performance is presented in Figure 1.

\section{[Insert Figure 1]}

Cognitive conflict. Cognitive conflict refers to task-oriented differences in judgment or issuerelated disagreement among directors (Forbes and Milliken, 1999). Groups performing an intellectual task are more effective if their members can express multiple viewpoints and exchange positive and negative comments (Watson and Michaelsen, 1988). Cognitive conflict may arise in boardrooms because directors are a diverse group of successful people facing complex decisions. Board members are likely to have different perceptions of the issues and different opinions on the most appropriate solutions (Dutton and Jakson, 1987). Boards show a large variance in the degree to which they experience cognitive conflict (Lorsch and MacIver, 1989; Mace, 1971; Monks and Minow, 1995). Whereas some boards tend to ratify 
and 'rubber stamp' decisions taken elsewhere by top managers, other boards have been able to develop structures and processes that promote open debate and positive disagreement. This affects the board service task in that conflict and disagreements may induce the CEO and the other top managers to consider other strategic alternatives or to evaluate more carefully the ones on the table (Forbes and Milliken, 1999). Disagreement and critical investigation are beneficial also to the board monitoring performance as long as open debate makes it easier for directors to raise critical questions, to ask top managers for more information, to gain a clearer picture of the firm's situation and to openly express a personal judgment on managerial behaviors (Stiles and Taylor, 2001). Finally, the presence of cognitive conflict inside the boardroom may intensify the feeling of urgency and increase the perception of the need to resort to external resources, thus improving board networking task performance (Hillman and Dalziel, 2003; Pfeffer \& Salancik, 1978). In sum, we hypothesize that the higher the cognitive conflict, the higher the level of board service, monitoring, and networking task performance.

Hypothesis 1a: Board cognitive conflict is positively related to board service task performance.

Hypothesis 1b: Board cognitive conflict is positively related to board monitoring task performance.

Hypothesis 1c: Board cognitive conflict is positively related to board networking task performance.

Effort norms. Effort norms refer to the board's shared beliefs on the level of effort each director is expected to put towards a task. Social norms play an important role in regulating the level of individual effort in groups, especially in collegial groups consisting of interdependent persons (Wageman, 1995). Directors are busy people facing many competing demands for their time (Lorsch and MacIver, 1989; Mace, 1971). Thus, strong effort norms can be expected to enhance the effort of each individual director (Forbes and Milliken, 1999). There is a large variance in the time and attention that boards of directors devote to accomplish their tasks (Lorsch and MacIver, 1989: 104-105). Some boards do not meet frequently and limit themselves to a formalized assessment (i.e., rubber stamp) of top management proposals (Mace, 1971; Stiles and Taylor, 2001). In other boards, directors actively participate in discussions, make the best use of their skills to perform board activities, make themselves available for the execution of specific tasks, and so on (Lorsch and MacIver, 
1989; Monks and Minow, 1995; Stiles and Taylor, 2001). We expect that higher amounts of time and higher levels of commitment devoted by directors to performing their tasks lead to significant increases in the degree to which boards are able to make useful contributions to strategy formulation, to control management behavior, and to facilitate the access to critical resources. In sum, the higher the board effort norms, the higher the level of board service, monitoring, and networking task performance.

Hypothesis 2a: Board effort norms are positively related to board service task performance. Hypothesis 2b: Board effort norms are positively related to board monitoring task performance.

Hypothesis 2c: Board effort norms are positively related to board networking task performance.

Use of knowledge and skills. Use of knowledge and skills refers to the process by which directors' contributions are coordinated (Forbes and Milliken, 1999). The group’s ability to extract individual knowledge and skills is an important criterion of its effectiveness (Wageman, 1995). The presence of professional (e.g., finance, marketing, accounting, law) and firm-specific knowledge and skills in the board does not imply per se that the board will be effective in performing its tasks. An effective board requires the active use and integration of the directors' expertise and skills for the benefit of group decisions. In other words, in effective boards, the extraction and integration of individual knowledge and skills is enabled by internal processes: a clear division of labor assigns specific activities and tasks to individual directors; the delegation of tasks to individual directors takes into account expertise and responsibilities; information flows smoothly between directors (Finkelstein and Mooney, 2003). In sum, we hypothesize that the higher the use of knowledge and skills, the higher the level of board service, monitoring and networking task performance.

Hypothesis 3a: Board use of knowledge and skills is positively related to board service task performance.

Hypothesis 3b: Board use of knowledge and skills is positively related to board monitoring task performance.

Hypothesis 3c: Board use of knowledge and skills is positively related to board networking task performance. 


\section{METHODS}

\section{The Italian setting}

The Italian corporate governance system differs from both the Anglo-Saxon outsider system and the German-Japanese insider system. Italy, together with other European countries (such as France, Spain, Belgium, Portugal and Greece), can be classified in the Latin subgroup characterized by controlling shareholders, strong inter-company ties and a weak role of capital markets (De Jong, 1997).

Italian companies are traditionally controlled by a large blockholder, usually a family. Banks and other financial institutions do not own large shareholdings and do not usually exert a significant influence on the governance of large companies. Institutional investors do not play a relevant role because of their limited shareholdings, their strict connections with the Italian banks and a regulatory environment that does not favor their activism. Finally, the stock market plays a limited role and the market for corporate control is almost absent (Melis 1999 and 2000).

Large blockholders, especially wealthy families, maintain the control of large listed companies through a vast array of governance mechanisms: the listing of many companies belonging to the same group, the issue of shares with limited voting rights, high leverage, mutual inter-group shareholdings, and shareholders' agreements (Zattoni, 1999). In sum, the Italian governance system can be described as a system of 'weak managers, strong blockholders and unprotected minority shareholders' (Melis, 2000: 354).

The board of directors is traditionally one tier, but the shareholders' general meeting must appoint also a board of statutory auditors whose main task is to monitor the directors' performance (Melis, 2004). Published studies showed that during the '90s the board of directors in Italy was under the direct influence of large blockholders: its composition was characterized by the presence of inside directors or outside directors related to the controlling shareholders by family or business ties, the executive committee tended to absorb most of the board key tasks, there were few board meetings, the information sent to directors was incomplete and filtered by managers, there was neither an ex ante definition nor an ex post formal evaluation of directors’ contribution (Molteni, 1997; Melis, 1999 and 2000).

Recent reforms in commercial law (1998, 2003, and 2005) and the introduction and update of a code of best practice (1999, 2002, and 2006) have contributed to radically change the Italian governance system. The legal reforms strengthen investors' protection by regulating relevant issues such as public bids, shareholders’ agreements, minority shareholders’ rights, internal controls, corporate groups, and the board of directors. At the same time the code of best 
practice has contributed to improve governance practices at board level, by encouraging transparency in the appointment of directors, a larger proportion of non-executive and independent directors, the introduction of a lead independent director in firms with CEO duality, the adoption of boards committees, the definition of stringent internal control systems, a more active role of statutory auditors, and the monitoring of transactions with third parties. These institutional changes have contributed to improve governance standards and to empower boards of directors in large Italian companies (Zattoni, 2006).

\section{Sample and data collection}

The sample frame for this study consisted of the 2,000 largest Italian manufacturing firms ranked by sales, extracted from Dun \& Bradstreet. In June 2004, we sent a questionnaire to all the CEOs of these companies ${ }^{1}$. We decided to target the CEO given his knowledge of the strategy of the firm and our intention to study the advice and networking tasks (beyond the more traditional monitoring task) (Forbes and Milliken, 1999: 492-493). Our choice is in line with previous governance studies which also used primary data (Pearce and Zahra, 1991; Zahra, 1996; Zahra, Neubaum and Huse, 2000).

Surveys of top managers have often suffered from low response rates, less than 25 percent (Pettigrew, 1992; Westphal, 1999). To ensure the highest possible response rate, we followed the steps consolidated in survey research methodology (Carpenter and Westphal, 2001; Fowler, 1993, Groves, Cialdini and Couper, 1992): (1) an in-depth pre-test was used to streamline the questionnaire, making it more appealing and easier to complete; (2) requests for participation emphasized the need for further research on board of directors and tried to engage respondents' natural interest in the topic; and (3) in September 2004, the CEOs were sent a second letter and the questionnaire.

To enhance the construct validity of the survey measures, we conducted a pre-test and interviewed 12 board members (Fowler, 1993: 102). Feedbacks from participants were used to ensure that the questions captured the concepts as we intended. Each individual was then asked to identify questions that were unclear, difficult to answer or potentially subject to bias. These interviews were also aimed to improve the format of the survey, to modify its length and to ensure that questions were interpreted as expected. Multiple response formats were used to reduce response bias, and items measuring each construct were scattered throughout the survey (DeVellis, 1991). Moreover, we carefully worded questions to minimize the likelihood of a social desirability bias, using inputs from the pilot interviews. All our questions were close-ended. 
In total 301 CEOs responded, representing a response rate of 15.0 percent. In line with the Italian settings, these companies' ownership structure is characterized by the presence of a large blockholder with at least a $20 \%$ stake in the firm's equity.

To check for non-response bias, we collected archival data for companies in the larger sample frame. Data on the firms' characteristics were gathered from the AIDA and Datastream databases. For companies with complete data, we examined whether respondents and nonrespondents differed significantly on several variables using the Kolmogorov-Smirnov twosample test (Siegel and Castellan, 1988). The results provide consistent evidence across multiple variables that respondents and non-respondents come from the same population.

We ran a factor analysis for survey items related to all dependent and independent variables. The iterated principal factors method (promax rotation) showed that items loaded on six different factors as expected, with loadings for each item greater than .6 on one factor and less than .4 on the other. Specific items and Cronbach's alpha indicators for each variable are presented in the following section (see also Table 1).

\section{Dependent measures}

Data for our three dependent variables, board service performance, board monitoring performance, and board networking performance were collected through the survey and assessed with a 5-point Likert Scale. The wording of each question was developed from the qualitative research available (Demb and Neubauer, 1992; Lorsch and Maclver, 1989; Stiles and Taylor, 2001).

We define board service performance as the extent to which the board actively participates in strategic decision-making and the quality of its contribution to the CEO. Board service performance was measured as the extent to which (i) the board takes long-term strategic decisions; (ii) the board contributes to the implementation of strategic decisions; (iii) the board's suggestions frequently improve strategic decisions (Carpenter and Westphal, 2001; Forbes and Milliken, 1999; Stiles and Taylor, 2001; Zahra and Pearce, 1989). Cronbach’s alpha was .77 for the service scale.

We define board monitoring performance as the degree to which the board exerts its control function on the firm's activities and on the CEO's behavior. Board monitoring performance was measured as the extent to which the board (i) monitors the firm's financial position; (ii) ensures that the firm's activities are adequately controlled; (iii) monitors the CEO; (iv) controls plans and budgets (Forbes and Milliken, 1999; Stiles and Taylor, 2001). Cronbach’s alpha was .75 for the monitoring scale. 
We define board networking performance as the degree to which the board contributes to strengthen contacts with relevant stakeholders and legitimize the company in its environment. Board networking performance was measured as the extent to which the board (i) provides contacts with relevant stakeholders; (ii) contributes to legitimize the company (Hillman and Dalziel, 2003; Pfeffer and Salancik, 1978). Cronbach’s alpha was .82 for the networking scale.

In order to enhance the construct validity of our dependent variables, we correlated them with archival data on firm performance.

It has been noted that board members often compare their firm performance to the average industry performance (Meindl, Ehrlich, and Dukerich, 1985; Morck, Shleifer, and Vishny, 1989). Therefore we measured indicators of the firm performance in relation to its competitors in the same industry. In particular, we measured the distance of each firm's ROE from the median ROE of the most comparable firms (as measured by operating revenues; including the firm in question) in years 2002-2003-2004. We then calculated the improvements of the firm's ROE performance relative to its direct competitors in years 2002/03 and 2003/04. Finally, we averaged these improvements, in order to identify the structural pattern of the firm performance.

Our results show a positive and significant correlation between this measure of the firm's relative performance and our measure of board service performance ( $r=.137, n=210, p<$ .05). We also find a positive and significant correlation between the firm's relative performance and the board monitoring performance $(r=.188, n=210, p<.01)$. Finally, the correlation between the firm relative performance and our measure of networking performance is positive and significant $(r=.139, n=211, p<.05)$.

\section{Independent measures}

Data for our independent variables, cognitive conflict, effort norms, and use of knowledge and skills were gathered through a survey and assessed with a 5-point Likert Scale. In order to enhance the construct validity of the survey measures, we carried out the same pre-test for independent variables as we had conducted for dependent variables.

Cognitive conflict was measured with a multi-item scale for task conflict developed by Jehn (1995). Specific items assess how frequently there are conflicts and disagreements (i) among directors; (ii) on decisions to be taken; (iii) on how the board should work; (iv) on how to pursue the firm's goal. Cronbach's alpha for this scale was .86.

Effort norms was measured following Wageman's (1995) example. Specific items assess the 
extent to which directors (i) use their skills and knowledge to fulfil board tasks; (ii) are available when needed; (iii) devote all the time needed to complete the task assigned; (iv) participate actively during meetings. Cronbach’s alpha for this scale was .76.

Use of knowledge and skills was measured drawing on past literature (Forbes and Milliken, 1999; McGrath, MacMillan and Venkataraman, 1995). Specific items assess the extent to which (i) task delegation on the board represents a good match between knowledge and responsibilities; (ii) there is a clear division of labor among directors; (iii) information flows quickly among board members. Cronbach’s alpha for this scale was .79.

\section{[Insert Table 1]}

\section{Control measures}

We selected demographic measures from the literature on boards of directors. The demographic variables most commonly considered in these studies are board size, outsider ratio, CEO duality, CEO ownership and the percentage of owner-directors (Brunninge \& Nordqvist 2004; Daily, Dalton and Cannella, 2003; Dalton et al., 1998; Dalton et al., 2003; Johnson, Daily and Ellstrand, 1996). Given the characteristics of our sample, CEO ownership controls for the possibility that the CEO may also be a blockholder of the firm. We also considered the percentage of owner directors - i.e., the number of directors holding shares in the firm divided by the total number of directors - since in Italy some directors may be tied to the firm via stock holdings.

We controlled for firm characteristics: firm size, measured as the logarithmic transformation of sales, and listing (Pye and Pettigrew, 2005). We also controlled for industry regulation (Pye and Pettigrew, 2005). We measured industry regulation by asking the CEO to rate it on a 5-point Likert scale.

\section{RESULTS}

Table 2 provides means, standard deviations, and bivariate correlations for all variables.

\section{[Insert Table 2]}

We used multiple Ordinary Least Squares (OLS) regression analysis since all our dependent variables are continuous and the independent variables are continuous or categorical. Collinearity diagnostics showed that regression results are not affected by multicollinearity 
among independent variables. The tolerance statistics of our independent variables are all well above 0.6, much higher than the minimum threshold of 0.2 (Menard, 1995).

Results of the multiple regression analysis testing hypothesis 1a, 2a, 3a support the prediction that Effort norms $(\mathrm{t}=.41 ; \mathrm{p}<.001)$ and Use of knowledge and skills $(\mathrm{t}=.17 ; \mathrm{p}<.01)$ are positively associated with board service task performance, whereas the coefficient of Cognitive conflict is not significant. Among control variables, only industry regulation has a weak positive relationship with board service performance $(\mathrm{t}=.09 ; \mathrm{p}<.10)$.

In respect of the board monitoring task performance, results of the multiple regression analysis testing hypothesis $1 \mathrm{~b}, 2 \mathrm{~b}, 3 \mathrm{~b}$ support the prediction that Effort norms $(\mathrm{t}=.22 ; \mathrm{p}<.001)$ and Use of knowledge and skills $(\mathrm{t}=.19 ; \mathrm{p}<.001)$ are positively associated with board monitoring performance, whereas the coefficient of Cognitive conflict is not significant. Among board demographic variables, only the coefficient of board size is significant and positive $(\mathrm{t}=.14 ; \mathrm{p}<.05)$. Results also showed that board monitoring is higher in listed companies $(\mathrm{t}=.19 ; \mathrm{p}<.001)$ and in firms operating in regulated industries $(\mathrm{t}=.13 ; \mathrm{p}<.05)$.

Finally, with respect to hypothesis 1c, 2c, and 3c, our results support the idea that Cognitive conflict $(\mathrm{t}=.14 ; \mathrm{p}<.05)$, Effort Norms $(\mathrm{t}=.12 ; \mathrm{p}<.10)$ and Use of knowledge and skills $(\mathrm{t}=.17$; $\mathrm{p}<.05)$ positively impact on board networking task performance. As for the demographic variables, we find owner-directors ratio $(\mathrm{t}=.13 ; \mathrm{p}<.05)$ and outsider ratio $(\mathrm{t}=.12 ; \mathrm{p}<.10)$ to be positively related to board networking performance. Moreover, networking task performance is higher in regulated industries $(\mathrm{t}=.14 ; \mathrm{p}<.05)$.

\section{[Insert Table 3]}

\section{DISCUSSION}

In recent years scholars of boards of directors have called for new studies to be based on approaches other than the dominant agency framework. Furthermore, the ability of demographic variables to catch the real factors leading to superior board performance has been questioned, and the use of process variables has been called for (Dalton et al. 1998; Daily, Dalton and Cannella, 2003; Johnson, Daily and Ellstrand, 1996; Pitcher, Chreim and Kisfalvi, 2000; Pye and Pettigrew, 2005; Roberts, McNulty and Stiles, 2005). In this paper we have addressed both these issues: we have considered boards as workgroups performing different tasks and have analyzed the impact of internal processes on three different board task performances. The paper provides an empirical test of theoretical propositions aimed at opening up the "black box", focusing on board internal processes in order to overcome the 
limitations of demographic variables (Forbes and Milliken, 1999; Huse, 2005; Pettigrew, 1992; Pye and Pettigrew, 2005).

We believe that our findings contribute to improving our understanding of what determines board performance. In particular, our study shows that (a) process variables and, to a lesser extent, demographic variables significantly influence board task performance; (b) board processes have a different impact on each specific board task; (c) board task performance varies according to various characteristics of the firm and industry.

Firstly, extant literature on board of directors analyzed the relationship between demographic variables and firm performance, without finding consistent empirical evidence (Daily, Dalton and Cannella, 2003; Dalton et al. 1998; Johnson, Daily and Ellstrand, 1996; Pye and Pettigrew, 2005). Instead of focusing on the firm performance, in this paper we analyzed the relationship between board demography, board processes and board task performance. Our results indicate that board processes, in particular effort norms and use of knowledge and skills, significantly influence board task performance. Board demographic characteristics also play a role: board size has been found to positively influence board monitoring performance; the outsider ratio and owner-directors ratio are positively associated with the networking task performance. Even if we cannot draw conclusive results, our study does suggest that more research is needed on how demographic variables and process variables may interact or jointly influence the board task performance.

Secondly, our results show that board service, monitoring, and networking task performance are influenced differently by board processes (Kula, 2005; Pettigrew and McNulty, 1998; Wan and Ong, 2005). With regards to board networking performance, both Cognitive conflict and Use of knowledge and skills have been found to positively influence board task performance, whereas we have found only weak support for the hypothesized positive relationship between Effort norms and board networking performance. On the contrary, when it comes to board service and monitoring performance, Use of knowledge and skills and Effort norms are positively associated with board performance, whereas Cognitive conflict does not exert any significant influence. These results seem to suggest that different board task performances may be differently influenced by board processes. In particular, the unrelatedness of Cognitive conflict to both service and monitoring task performance supports the idea advanced in organization studies that its effect on group performance may be ambiguous (Jehn, 1995): actually, cognitive conflict may favor the emergence of negative emotions among group-members, counterbalancing its positive effects on the group's task performance (Forbes and Milliken, 1999). Moreover, it is worth noting that the Use of 
knowledge and skills, i.e., the process by which members' contributions are coordinated, is positively associated with board task performances: this finding seems to suggest that in episodic decision-making groups facing complex tasks, such as boards of directors, a key factor determining board effectiveness is the way in which directors' individual skills and expertise are integrated. We maintain that board's outcome may be less than the sum of its parts if individual contributions are not well integrated (Forbes and Milliken, 1999; Pye and Pettigrew, 2005).

Our study also indicates that board task performance is higher in regulated industries and listed companies, suggesting that the external context does influence board conduct and may shape the criteria against which board effectiveness can be measured (Pye and Pettigrew, 2005). In particular, they suggest that external scrutiny - by financial investors as in the case of listed corporations and by regulatory authorities as in the case of companies operating in regulated industries - encourages the boards to accomplish their tasks more effectively.

The study has some limitations that may provide opportunities for future work. First, following the indications of Jehn (1995) and Forbes and Milliken (1999), we measured cognitive conflict asking respondents to estimate its intensity (see table 1). As Eisenhardt and Bourgeois (1988) have noted, conflict needs to be brought to the surface and then resolved. Drawing on a richer qualitative approach (Ravasi and Zattoni, 2006), future studies may include the resolution of the cognitive conflict among directors and deepen our knowledge on how it may affect decision-making processes in the boardroom.

Second, following previous governance studies (Pearce and Zahra, 1989; Zahra, 1996; Zahra, Neubaum and Huse, 2000), our research is based on a single respondent, i.e., the CEO. Governance scholars traditionally choose to target the CEO because of the many difficulties of gaining access to primary data (Daily, Dalton and Cannella, 2003). Even if we did validate our measures of board task performance by correlating them with archival data, the choice to target the CEO may represent a limitation of this study. The Chairperson could also have been used as a respondent given his role inside the board. Either choice - the CEO or the Chairperson - may be pursued because the Chairperson is in charge of managing the board, while the CEO is in charge of managing the company. To strengthen our knowledge of how board processes influence board task performance, future studies may try to have multiple respondents, including the valuation of the Chairperson and of other directors.

Third, in common with the large majority of research on corporate governance, our study is based on a cross sectional analysis. A recent review of papers published in six leading general management journals showed that the 127 empirical studies of boards of directors which had 
been published in the period 1990-2002 were largely biased toward cross-sectional research design (Gabrielsson and Huse, 2004). To improve our knowledge of the dynamic configuration of governance structures and processes, future studies should take a longitudinal perspective by comparing and contrasting data and analyses over several years. The participant observation method could be very profitable for this purpose (Samra-Fredericks, 2000a and 2000b).

This paper has also some implications for practitioners. Corporate governance literature has traditionally focused on a limited number of board characteristics (i.e., board size, CEO duality, outsider ratio) as a determinant of board effectiveness. Nowadays, the emerging corporate governance ratings evaluate a wider range of criteria, but all these criteria are also focused on the structural characteristics of boards (Van den Berghe and Levrau, 2004). Our findings support the view that board task performance is not only related to how boards are structured and that demographic variables do not automatically lead to more effective boards (Finkelstein and Mooney, 2003). In our study we show that the effectiveness of boards of directors is strongly influenced by group-level processes such as open and critical debate (cognitive conflict), directors' commitment to fulfilling their role (effort norms), and the coordination of directors' contribution (use of knowledge and skills) (Forbes and Milliken, 1999). Overall, our analysis supports the idea that board design involves both structural and process variables (Finkelstein and Mooney, 2003; Forbes and Milliken, 1999; Pye and Pettigrew, 2005; Roberts, McNulty and Stiles, 2005).

In sum, in order to create well-functioning boards it is not sufficient to demand changes in board demography, i.e., to add more independent directors, as codes of good governance recommend. On the contrary, boards wanting to improve their task performance must devote more attention to their internal processes (Finkelstein and Mooney, 2003; Pye and Pettigrew, 2005). Much work needs to be done: we believe that peer-evaluation of board practices and training may dramatically improve the board's contribution to the firm performance.

\section{Conclusions}

Our research explores the relationship between board processes and board task performance, using primary data to open up the black box of board demography. We contribute to the extant literature on boards of directors by showing that board processes influence board task performance, and that board demographic variables may also play a role. Research on boards should consider both demographic and process variables as antecedents of board performance in its service, monitoring and networking tasks. Future research on board decision-making 
and processes is needed to have a much clearer picture of how board demography and processes interact and influence board task performance. Researchers are invited to draw on existing literature on group dynamics and effectiveness and to use qualitative methods, such as case studies, to gain a clearer understanding of board dynamics.

Since directors may exert informal influence on managerial behavior outside regular meetings, future research may focus on the actual behavior of directors (inside and outside the boardroom) with the aim of analyzing when and how they contribute to board effectiveness (Pettigrew and McNulty, 1998). Moreover, we believe that the contribution provided by directors may depend upon their appointment to a specific committee (Klein, 1998): in our opinion, in future studies it would be interesting to assess how a director's participation in committees may influence board processes and the group performance. Finally, governance scholars should pay attention to the inner and outer contexts, since we feel they may play a role in how board processes influence board task performance (Pye and Pettigrew, 2005).

\section{NOTES}

1. Governance studies incorporating primary data are traditionally based on a single respondent, typically the CEO (Pearce and Zahra, 1991; Zahra, 1996; Zahra, Neubaum and Huse, 2000). This is due to difficulties in gaining access to process data on boards of directors, given the inherent confidentiality of their activities (Daily, Dalton and Cannella, 2003; Pettigrew, 1992; Pye, 2001). Furthermore, recent scandals and governance reforms have, if anything, contributed to further reducing the access of governance scholars to board members because of the increased fear of legal action against them. 


\section{REFERENCES}

Andrews, K. (1980) Directors' Responsibility for Corporate Strategy, Harvard Business Review, 58: 30-42.

Berle, A. and Means, G. (1932) The Modern Corporation and Private Property. New York: MacMillan.

Bettenhausen, K. (1991) Five Years of Group Research: What We Have Learned and What Needs to be Addressed, Journal of Management, 17: 345-381.

Brunninge, O. and Nordqvist, M. (2004) Ownership Structure, Board Composition, and Entrepreneurship: Evidence from Family Firms and Venture-Capital Back Firms, International Journal of Entrepreneurial Behavior \& Research, 10 (1/2): 85-105.

Carpenter, M.A. and Westphal, J.D. (2001) The Strategic Context of External Network Ties: Examining the Impact of Director Appointments on Board Involvement in Strategic Decision Making, Academy of Management Journal, 4 (4): 639-660.

Daily, C.M., Dalton, D.R. and Cannella, A.A. (2003). Corporate Governance: Decades of Dialogue and Data, Academy of Management Review, 28 (3): 371-382.

Daily, C.M., Dalton, D.R. and Rajagopalan N. (2003), Governance through ownership: centuries of practice, decades of research, Academy of Management Journal, 46 (2), 151-158.

Dalton, D.R., Daily, C.M., Certo, S.T. and Roengpitya, R. (2003) Meta-analyses of financial performance and equity: Fusion or confusion?, Academy of Management Journal, 46: 13-26.

Dalton, D.R., Daily, C.M., Ellstrand, A.E. and Johnson, J.L. (1998) Meta-analytic Reviews of Board Composition, Leadership Structure and Financial Performance, Strategic Management Journal, 19: 269-290.

Davis, J.H., Schoorman, F.D. and Donaldson, L. (1997) Toward a Stewardship Theory of Management, Academy of Management Review, 22: 20-47.

De Jong, H.W. (1997) The Governance Structure and Performance of Large European Corporations, Journal of Management and Governance, 1: 5-27.

Demb, A. and Neubauer, F.F. (1992) The Corporate Board. New York: Oxford University Press. 
DeVellis, R.F. (1991) Scale Development: Theory and Applications. Newbury Park: Sage.

Dutton, J. and Jackson, S. (1987) Categorizing Strategic Issues: Links to Organizational Action, Academy of Management Review, 12: 76-90.

Eisenhardt, K.M. and Bourgeois III, L.J. (1988) Politics of Strategic Decision Making in High-Velocity Environments: Toward a Midrange Theory, Academy of Management Journal, 31 (4): 737-770.

Fama, E. and Jensen, M. (1983) Separation of Ownership and Control, Journal of Law and Economics, 26: 301-325.

Finkelstein, S. and Mooney, A.C. (2003) Not the Usual Suspects: How to Use the Board Process to Make Boards Better, Academy of Management Executive, 17(2): 101-113.

Forbes, D.P. and Milliken, F.J. (1999) Cognition and Corporate Governance: Understanding Boards of Directors as Strategic Decision-Making Groups, Academy of Management Review, 24: 489-505.

Fowler, F.J. (1993) Survey Research Methods. Newbury Park: Sage.

Gabrielsson, J. and Huse, M. (2004) Context, behavior, and evolution. Challenges in research on boards and governance, International Studies of Management and Organization, 34 (2): 11-36.

Goodstein, J., Gautam, K. and Boeker, W. (1994) The Effects of Board Size and Diversity on Strategic Change, Strategic Management Journal, 15: 241-250.

Groves, R. M., Cialdini, R.B. and Couper, M.P. (1992) Understanding the Decision to Participate in a Survey, Public Opinion Quarterly, 56: 475-495.

Hermalin, B.E. and Weisbach, M.S. (2003) Boards of directors as an endogenously determined institution: A survey of the economic literature, Economic Policy Review, April 9(1): 7-26.

Hillman, A.J. and Dalziel, T. (2003) Boards of Directors and Firm Performance: Integrating Agency and Resource Dependence Perspectives, Academy of Management Review, 28 (3): 383-396.

Huse, M. (2000) Board of directors in SMEs: a review and research agenda, Entrepreneurship \& Regional Development, 12: 271-290.

Huse, M. (2005) Accountability and creating accountability: a framework for exploring 
behavioral perspectives of corporate governance, British Journal of Management, 16: 65-79.

Jehn, K. (1995) “A Multimethod Examination of the Benefits and Detriments of Intragroup Conflict”, Administrative Science Quarterly, 40: 256-282.

Jensen, M.C. and Meckling, W.H. (1976) Theory of the Firm: Managerial Behavior, Agency Costs, and Capital Structure, Journal of Financial Economics, 3: 305-360.

Johnson, J.L., Daily, C. M. and Ellstrand, A. E. (1996) Boards of Directors: A Review and Research Agenda, Journal of Management, 22 (3): 409-438.

Judge, W.Q. and Zeithaml, C. P. (1992) Institutional and Strategic Choice Perspective on Board Involvement in the Strategic Decision Process, Academy of Management Journal, 35 (4): 766-794.

Klein, A. (1998) Firm performance and board committee structure, Journal of Law and Economics, 41: 275-303.

Kula, V. (2005) The impact of roles, structure and process of boards on firm performance: evidence from Turkey, Corporate Governance: An International Review, 13 (2): 265276.

Lawrence, B. (1997) The Black Box of Organizational Demography, Organization Science, 8: $1-22$.

Lorsch, J.W. and MacIver, E. (1989) Pawns or Potentates - The Reality of America's Corporate Boards. Boston: Harvard Business School Press.

Mace, M. L. (1971) Directors: Myth and Reality. Boston: Harvard Business School Press.

McGrath, R., MacMillan, I. and Venkataraman, S. (1995) Defining and Developing Competence: A Strategic Process Paradigm, Strategic Management Journal, 16: 251275.

McNulty, T. and Pettigrew, A. (1999) Strategists on the Board, Organization Studies, 20/1, 47-74.

Meindl, J.R., Ehrlich, S.B. and Dukerich, J.M. (1985), The romance of leadership, Administrative Science Quarterly, 30, 78-102.

Melis, A. (1999) Corporate governance - Un'analisi empirica della realtà italiana in un’ottica europea. Torino: Giappichelli. 
Melis, A. (2000) Corporate Governance in Italy, Corporate Governance: An International Review, 8 (4): 347-355.

Melis, A. (2004) On the Role of the Board of Statutory Auditors in Italian Listed Companies, Corporate Governance: An International Review, 12 (1): 74-84.

Menard, S. (1995) Applied logistic regression analysis, Sage University paper on quantitative applications in the social sciences, 07-106. Thousands Oaks, CA: Sage.

Milliken, F. and Vollrath, D. (1991) Strategic decision-making tasks and group effectiveness: Insights from theory and research on small group performance, Human Relations, 44: 125.

Molteni, M. (1997) “I sistemi di corporate governance nelle imprese italiane di medie e grandi dimensioni”, in: Molteni, M. (ed.), I sistemi di corporate governance nelle grandi imprese italiane, Milano: Egea.

Monks, R. and Minow, N. (1995) Corporate Governance. Cambridge: Basil Blackwell.

Morck, R., Shleifer, A. and Vishny, R.W. (1989), Alternative mechanisms for corporate control, American Economic Review, 79, 842-852.

Nunnally, J. (1978) Psychometric Theory (2 ${ }^{\text {nd }}$ ed.). New York: McGraw-Hill.

Pearce, J.A. and Zahra, S.A. (1991) The Relative Power of CEOs and Boards of Directors: Associations with Corporate Performance, Strategic Management Journal, 12: 135-153.

Pettigrew, A.M. (1992) On Studying Managerial Elites, Strategic Management Journal, 13, 163-182.

Pettigrew, A.M. and McNulty, T. (1998) Sources and uses of power in and around the boardroom, European Journal of Work and Organizational Psychology, 7(2): 197-214.

Pfeffer, J. (1972) Size and composition of corporate board of directors, Administrative Science Quarterly, 17: 221-228.

Pfeffer, J. (1983) Organizational Demography. In L.L. Cummings ad B.M. Staw (Eds.), Research in Organizational Behavior, vol. 5: 299-357. Greenwich: JAI Press.

Pfeffer, J. and Salancik, G. (1978) The External Control of Organizations. New York: Harper \& Row.

Pitcher, P., Chreim, S. and Kisfalvi, V. (2000) CEO Succession Research: Methodological Bridges Over Troubled Waters, Strategic Management Journal, 21: 625-648. 
Pye, A. (2001) A study in studying corporate boards over time: Looking backwards to move forwards, British Journal of Management, 12: 33-46.

Pye, A. and Pettigrew, A.M. (2005) Studying board context, process and dynamics: some challenges for the future, British Journal of Management, 16: 27-38.

Ravasi, D. and Zattoni, A. (2006) Exploring the Political Side of Board Involvement in Strategy: A Study of Mixed-Ownership Institutions, Journal of Management Studies, 43 (8), 1673-1703.

Roberts, J., McNulty, T. and Stiles, P. (2005) Beyond agency conceptions of the work of the non-executive director: Creating accountability in the boardroom, British Journal of Management, 16: 5-26.

Samra-Fredericks, D. (2000a) Doing 'Boards-in-Action' Research - An Ethnographic Approach for the Capture and Analysis of Directors' and Senior Managers' Interactive Routines, Corporate Governance: An International Review, 8 (3): 244-257.

Samra-Fredericks, D. (2000b) An Analysis of the Behavioral Dynamics of Corporate Governance - A Talk Based Ethnography of a UK Manufacturing 'Board-in-Action', Corporate Governance: An International Review, 8 (4): 311-326.

Shleifer, A. and Vishny, R. (1997) A Survey of Corporate Governance, Journal of Finance, 52: 737-783.

Siegel, S. and Castellan, N.J. (1988) Nonparametric Statistics for the Behavioral Sciences (2 ${ }^{\text {nd }}$ ed.). New York: McGraw-Hill.

Stiles, P. and Taylor, B. (2001) Boards at Work - How Directors View their Roles and Responsibilities. Oxford: Oxford University Press.

Van den Berghe, L.A. and Levrau, A. (2004) Evaluating Boards of Directors: What Constitutes a Good Corporate Board?, Corporate Governance: An International Review, 12(4): 461-478.

Wageman, R. (1995) Interdependence and Group Effectiveness, Administrative Science Quarterly, 40: 145-180.

Wan, D. and Ong, C.H. (2005) Board structure, process and performance: evidence from public-listed companies in Singapore, Corporate Governance: An International Review, 13 (2): 277-290. 
Watson, W. and Michaelsen, L. (1988) Group interaction behaviors that affect group performance on an intellective task, Group \& Organization Studies, 13: 495-516.

Westphal, J.D. (1999) Collaboration in the boardroom: behavioral and performance consequences of CEO-board social ties, Academy of Management Journal, 42 (1): 7-24.

Zahra, S.A. (1996) Governance, Ownership, and Corporate Entrepreneurship. The Moderating Impact of Industry Technological Opportunities, Academy of Management Journal, 39: 1713-1735.

Zahra, S.A. and J. A. Pearce, (1989), Boards of Directors and Corporate Financial Performance: A Review and Integrative Model, Journal of Management, 15 (2): 291334.

Zahra, S.A., Neubaum, D.O. and Huse, M. (2000) Entrepreneurship in Medium Size Companies: Exploring the Effects of Ownership and Governance Systems, Journal of Management, 26: 947-976.

Zattoni, A. (1999) The Structure of Corporate Groups: The Italian Case, Corporate Governance - An International Review, 7 (1): 38-48.

Zattoni, A. (2006) Assetti proprietari e corporate governance. Milano: Egea. 
Figure 1: The theoretical model

Board

processes
Board task performance

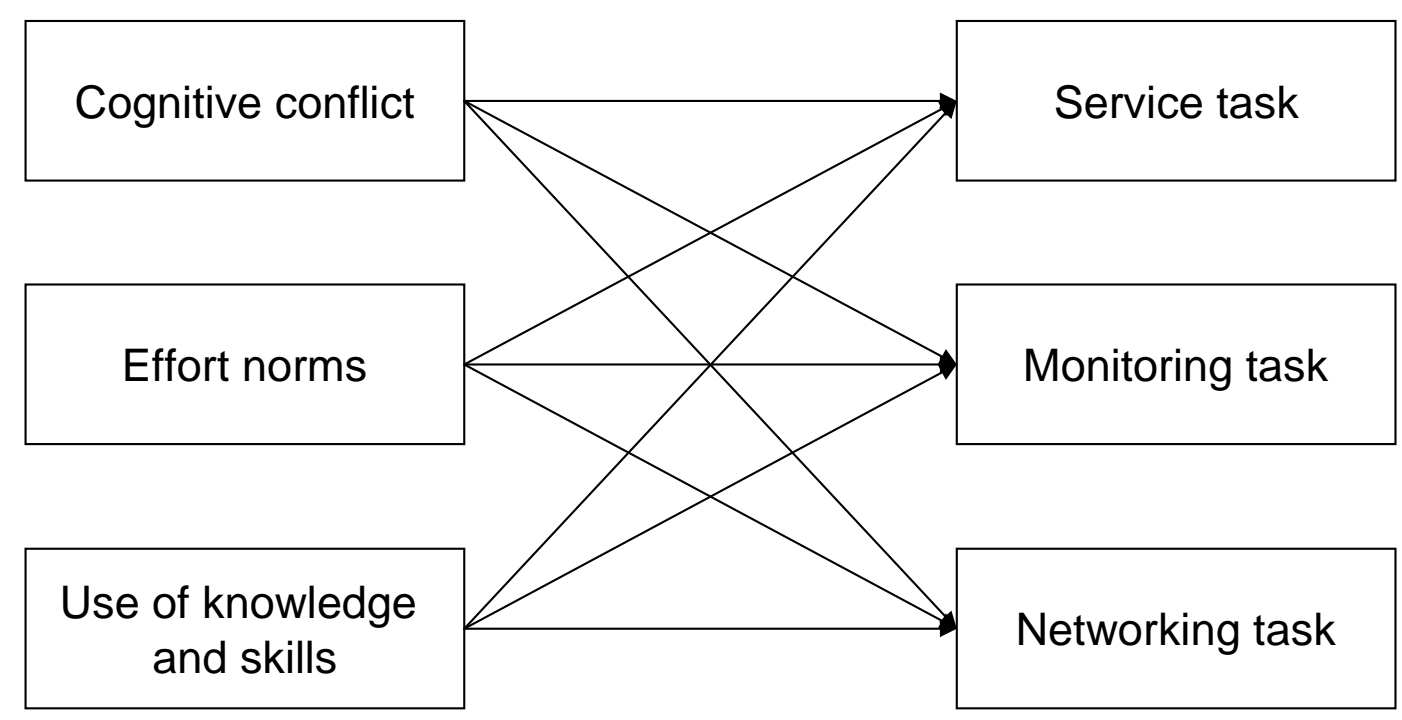


Table 1

Factor loadings and Cronbach's Alpha

Service

The board contributes to the implementation of strategic decisions

The board takes long-term strategic decisions

factor

loadings

C-Alfa

0.77

Board's suggestions frequently improve strategic decisions

0.79

0.76

0.68

\section{Monitoring}

0.75

The board ensures firm's activities to be adequately controlled

0.81

The board monitors the firm's financial position

0.70

The board controls plans and budgets

0.64

The board monitors the CEO

0.54

\section{Networking}

The board contributes to legitimize the company

0.85

The board provides contacts with relevant stakeholders

0.84

\section{Cognitive conflict}

There are frequently conflicts and disagreements among directors

There are frequently conflicts and disagreements on decisions to be taken

There are frequently conflicts and disagreements on how the board should work

There are frequently conflicts and disagreements on how to pursue the firm's goal

\section{Effort norms}

Directors use their skills and knowledge to fulfill board tasks

Directors are available when needed

Directors devote all the time needed to complete the task assigned

0.67

Directors actively participate during meetings

\section{Use of knowledge and skills}

Task delegation on the board represents a good match between knowledge and responsibilities 
TABLE 2

Descriptive Statistics and Pearson Correlation Coefficients

\begin{tabular}{|c|c|c|c|c|c|c|c|c|c|c|c|c|c|c|c|}
\hline Variable & Mean & sd & 1 & 2 & 3 & 4 & 5 & 6 & 7 & 8 & 9 & 10 & 11 & 12 & \\
\hline 1. Service & 3.41 & 0.96 & & & & & & & & & & & & & \\
\hline 2. Monitoring & 3.60 & 0.86 & .55 & & & & & & & & & & & & \\
\hline 3. Networking & 2.66 & 1.17 & .36 & .33 & & & & & & & & & & & \\
\hline 4. Cognitive conflict & 1.73 & 0.76 & .00 & .00 & .10 & & & & & & & & & & \\
\hline 5. Effort norms & 4.06 & 0.72 & .50 & .33 & .21 & -.12 & & & & & & & & & \\
\hline 6. Use of knowledge \& skills & 3.72 & 0.91 & .39 & .25 & .18 & -15 & .50 & & & & & & & & \\
\hline 7. Perc. owner-directors & 0.19 & 029 & .03 & -.06 & .16 & .05 & .09 & .14 & & & & & & & \\
\hline 8. CEO ownership & 0.09 & 0.20 & .00 & -.06 & .07 & -.09 & .03 & .07 & .23 & & & & & & \\
\hline 9. CEO duality & 0.30 & 0.46 & .01 & -.01 & -.02 & -.07 & .01 & -.09 & -.07 & .32 & & & & & \\
\hline 10. Outsider ratio & 0.45 & 0.34 & -.01 & .09 & .09 & -.00 & -.11 & -.23 & -.12 & -17 & -.07 & & & & \\
\hline 11. Board size & 7.25 & 4.11 & -.06 & .16 & .03 & -.00 & -.09 & -.17 & -.18 & -.14 & .03 & .45 & & & \\
\hline 12. Regulated industry & 2.92 & 1.55 & .13 & .18 & .15 & .07 & .08 & .00 & .05 & .02 & .01 & -.08 & -.05 & & \\
\hline 13. Listing & 0.24 & 0.42 & .09 & .28 & .17 & -.04 & .10. & -.02 & -.09 & -.00 & .05 & .33 & .30 & .07 & \\
\hline 14. Firm size & 5.56 & 1.59 & -.06 & .07 & -.05 & -.02 & 08 & -.12 & -.16 & .19 & -.05 & .10 & .13 & .08 & .10 \\
\hline
\end{tabular}

$n=301$ CEOs; for correlations lower than -.10 and greater than $.11 \quad p<.05$ 
TABLE 3

Results of Multiple Regressions Analysis ${ }^{\mathrm{a}}$

\begin{tabular}{|c|c|c|c|c|c|c|}
\hline \multirow[b]{2}{*}{ Independent Variables } & \multicolumn{2}{|c|}{$\begin{array}{c}\text { Hypothesis 1a, 2a, 3a } \\
\text { Service }\end{array}$} & \multicolumn{2}{|c|}{$\begin{array}{c}\text { Hypothesis } 1 \mathbf{b}, \mathbf{2 b}, \mathbf{3 b} \\
\text { Monitoring }\end{array}$} & \multicolumn{2}{|c|}{$\begin{array}{c}\text { Hypothesis 1c, 2c, 3c } \\
\text { Networking }\end{array}$} \\
\hline & Model 1 & Model 2 & Model 1 & Model 2 & Model 1 & Model 2 \\
\hline Cognitive conflict & & .07 & & .05 & & .14 * \\
\hline Effort norms & & $.41 * \star \star$ & & $.22 \star \star \star ~$ & & $.12^{\dagger}$ \\
\hline Use of knowledge and skills & & $.17 * \star$ & & $.19 \star \star \star$ & & $.17 *$ \\
\hline Perc. owner-directors & .06 & .00 & .00 & -.03 & $.17^{\star \star *}$ & $.13 *$ \\
\hline CEO ownership & -.03 & -.03 & .00 & -.01 & .06 & .07 \\
\hline CEO duality & .00 & .04 & -.05 & -.01 & -.05 & -.01 \\
\hline Outsider ratio & -.11 & -.03 & -.01 & .05 & .07 & $.12^{\dagger}$ \\
\hline Board size & -.03 & .01 & .10 & .14 * & .01 & .03 \\
\hline Regulated industry & .13 & $.09^{\dagger}$ & $.16 \star \star \star$ & $.13 *$ & $.15 *$ & $.14 *$ \\
\hline Listing & .15 & .07 & $.24 * \star \star$ & $.19 * \star \star$ & .14 * & .10 \\
\hline Firm Size & -.80 & -.10 & .02 & .03 & -.08 & -.07 \\
\hline$F$ & 1.70 * & $9.70 * \star \star$ & $4.14 * \star \star$ & $6.94 * * \star$ & $3.18 * \star \star$ & $4.19 * \star \star$ \\
\hline $\operatorname{Adj} R^{2}$ & $.02^{\dagger}$ & $.27^{\star \star \star}$ & $.09 * \star \star$ & $.21 * \star \star$ & $.06 * \star \star$ & 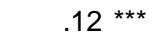 \\
\hline $\mathrm{D} R^{2}$ & & $.25 \star \star \star$ & & $.12 * \star \star$ & & $.06 * \star \star$ \\
\hline
\end{tabular}

\footnotetext{
${ }^{a}$ Standardized coefficients are reported in the table; $n=301$

${ }^{\dagger} p<.10$

$* p<.05$

** $p<.01$

*** $p<.001$
} 